\title{
Epidemiology of Blood Culture-proven Bacterial Sepsis in \\ Children in Switzerland - a Population-based Cohort Study
}

Philipp KA Agyeman, MD ${ }^{1} *$, Luregn J Schlapbach, MD ${ }^{1,2,3 *}$, Eric Giannoni, MD ${ }^{4,5}$, Martin Stocker, MD ${ }^{6}$, Klara M Posfay-Barbe, MD ${ }^{7}$, Professor Ulrich Heininger, MD ${ }^{8}$, Matthias Schindler, M.sc. ${ }^{9}$, Insa Korten, MD ${ }^{1,10}$, Gabriel Konetzny, MD ${ }^{11}$, Anita Niederer-Loher, MD ${ }^{12}$, Christian R Kahlert, MD ${ }^{12}$, Alex Donas, MD ${ }^{6}$, Antonio Leone, MD ${ }^{13}$, Paul Hasters, MD ${ }^{13}$, Christa Relly, MD ${ }^{14}$, Walter Baer, MD ${ }^{15}$, Professor Claudia E Kuehni, MD ${ }^{9}$, Professor Christoph Aebi, MD ${ }^{1}$, and Christoph Berger, MD ${ }^{14}$ for the Swiss Pediatric Sepsis Study

1. Department of Pediatrics, Inselspital, Bern University Hospital, University of Bern, Switzerland

2. Paediatric Critical Care Research Group, Mater Research Institute, University of Queensland, Brisbane, Australia

3. Paediatric Intensive Care Unit, Lady Cilento Children's Hospital, Children's Health Queensland, Brisbane, Australia

4. Department Woman-Mother-Child, Clinic of Neonatology, Lausanne University Hospital, Lausanne, Switzerland

5. Department of Medicine, Infectious Diseases Service, Lausanne University Hospital, Lausanne, Switzerland

6. Department of Pediatrics, Children's Hospital Lucerne, Lucerne, Switzerland

7. Pediatric Infectious Diseases Unit, Children's Hospital of Geneva, University Hospitals of Geneva and University of Geneva, Geneva, Switzerland

8. Infectious Diseases and Vaccinology, University of Basel Children's Hospital, Basel, Switzerland

9. Institute of Social and Preventive Medicine, University of Bern, Bern, Switzerland

10. University of Basel Children's Hospital, Basel, Switzerland

11. Children's Hospital Aarau, Aarau, Switzerland

12. Children's Hospital of Eastern Switzerland St. Gallen, St. Gallen, Switzerland

13. Department of Neonatology, University Hospital Zurich, Zurich, Switzerland

14. Division of Infectious Diseases and Hospital Epidemiology, and Children's Research Center, University Children's Hospital Zurich, Switzerland 
Author Manuscript Published in final edited form as: Lancet Child Adolesc Health. 2017 Oct;1(2):124-133 DOI: http://dx.doi.org/10.1016/S2352-4642(17)30010-X

15. Children's Hospital Chur, Chur, Switzerland

* equal contribution

\section{Correspondence}

Dr. Philipp Agyeman, MD, Inselspital, Bern University Hospital, University of Bern, 3010 Bern, Switzerland; Phone +41 (0)31 632 5065; Fax +41 (0)31 632 9416; email:

philipp.agyeman@insel.ch

and

A/Prof. Luregn J Schlapbach, MD, FCICM, Paediatric Critical Care Research Group, Mater Research Institute, University of Queensland, South Brisbane QLD 4101 Australia; Phone +61 (07) 3163 8111; Fax +61 (07) 3163 7556; email: 1.schlapbach@uq.edu.au 
Author Manuscript Published in final edited form as: Lancet Child Adolesc Health. 2017 Oct;1(2):124-133 DOI: http://dx.doi.org/10.1016/S2352-4642(17)30010-X

\section{Abstract}

\section{Background}

Sepsis is a leading cause of childhood mortality worldwide. We assessed population-based incidence and outcomes of blood culture-proven bacterial sepsis in children in Switzerland.

\section{Methods}

Multicenter national prospective cohort study including neonates and children $<17$ years with blood culture-proven bacterial sepsis from September 1, 2011, to December 31, 2015. Ten pediatric hospitals, including all five pediatric university hospitals, participated in the study. Children were eligible if they met criteria for systemic inflammatory response syndrome, as defined by 2005 pediatric consensus definition, at the time of blood culture sampling. Incidence was calculated by dividing the number of annual sepsis episodes in the study for the years 2012 to 2015 by the end of year resident pediatric population in Switzerland. The primary outcome was in-hospital mortality in the first 30 days after sepsis onset.

\section{Findings}

Of 1181 blood culture-proven bacterial sepsis episodes, 382 (32\%) occurred in previously healthy children, 402 (34\%) in neonates, and 397 (34\%) in children with comorbidities. The incidence was $25 \cdot 1 / 100 ' 000$ in children $(95 \%$-CI 23·8-26·4), and 146•0/100'000 in neonates $(133 \cdot 2-159 \cdot 6)$. Central line-associated bloodstream infection and primary bloodstream infection accounted for $48 \%(569 / 1181)$ of episodes. The case fatality ratio (CFR) was $7 \%$ and was higher in neonates (11\%, adjusted OR 4.41, 1.75-11·1) and children with comorbidities (7\%, OR 4.97, 1·84-13.4) compared to previously healthy children (3\%). The CFR was $1 \%$ in 726/1181 (61\%) episodes without organ dysfunction and increased to $17 \%$ in 455/1181 (39\%) episodes where an organ dysfunction was present (adjusted OR 4·84, 1·40-16·7).

\section{Interpretation}

The burden of blood culture-proven bacterial sepsis on child health remains considerable. We observed key differences in predominant organisms, severity, and outcome between neonates, previously healthy children and those with comorbidities. While the majority of blood cultureproven bacterial sepsis had no organ dysfunction, presence and number of organ dysfunctions were strongly associated with mortality. 
Author Manuscript Published in final edited form as: Lancet Child Adolesc Health. 2017

Oct;1(2):124-133 DOI: http://dx.doi.org/10.1016/S2352-4642(17)30010-X

\section{Funding}

Swiss National Science Foundation (342730_153158/1). Swiss Society of Intensive Care.

Bangerter Foundation. Vinetum and Borer Foundation. Foundation for the Health of Children and Adolescents.

\section{Keywords}

Bacteremia, Sepsis, Children, Pediatrics, Epidemiology, Case fatality rate 
Author Manuscript Published in final edited form as: Lancet Child Adolesc Health. 2017 Oct;1(2):124-133 DOI: http://dx.doi.org/10.1016/S2352-4642(17)30010-X

\section{Introduction}

Invasive bacterial infections represent one of the leading causes of childhood mortality worldwide. ${ }^{1}$ Neonates and young children are particularly susceptible to severe or lethal infections. ${ }^{2}$ Recent studies from the United States reported that the incidence of severe sepsis in children increased from 0.56 to 0.89 cases per 1,000 children over the past decade. ${ }^{3,4}$ In adults, bloodstream infections rank among the top seven causes of death in the US and Western Europe. ${ }^{5}$ The incidence of bloodstream infections is highest at the extremes of age, in neonates and the elderly, ${ }^{6}$ yet there is a lack of comprehensive population-based analyses on severe bacterial infections in childhood. In addition to age, host factors such as underlying disease are primary determinants of susceptibility and outcomes. ${ }^{7,8}$ Importantly, epidemiology of invasive infections is subject to change as a result of vaccination campaigns, ${ }^{9}$ and the increasing number of patients at risk of acquiring healthcare-associated infections including premature newborns, children with malignancies or after transplantation. ${ }^{10}$ Considering the detrimental effect of delays in antimicrobial treatment in bacterial sepsis, ${ }^{11}$ representative data on the contemporary burden of bacterial sepsis are key to guide national strategies for optimal antibiotic usage. ${ }^{12}$ Sepsis in adults was recently re-defined as a life-threatening organ dysfunction resulting from a dysregulated host response to infection. ${ }^{13}$ In contrast, the pediatric definition of sepsis is still based on the 2005 consensus $^{2}$ requiring the presence of systemic inflammatory response syndrome (SIRS) in patients with suspected infection, which have been criticized for lack of specificity to identify patients subgroups with substantially higher mortality. ${ }^{14}$ A limitation of larger studies on childhood sepsis consists in the use of clinical definitions of sepsis, with only a minority of sepsis episodes being microbiologically confirmed, and the lack of robust characterization of the presence and impact of organ dysfunction on outcomes.,

This population-based national prospective cohort study aimed to describe the epidemiology and severity of blood culture-proven bacterial sepsis, as defined by the 2005 consensus definitions, ${ }^{2}$ in children in Switzerland. We investigated patterns of blood culture-proven bacterial sepsis in relation to incidence, pathogens, severity, organ dysfunctions, and outcomes. 
Author Manuscript Published in final edited form as: Lancet Child Adolesc Health. 2017 Oct;1(2):124-133 DOI: http://dx.doi.org/10.1016/S2352-4642(17)30010-X

\section{Methods}

\section{Study design}

The Swiss Pediatric Sepsis Study ${ }^{15}$ is a prospective national observational multicenter cohort study investigating blood culture-proven bacterial sepsis in children in Switzerland from September 1, 2011, to December 31, 2015. All ten major children's hospitals in the country participated in the study, including all five pediatric University hospitals, and the five largest regional pediatric hospitals. During the study, these centers accounted for $78 \%$ of all hospital admissions, and $98 \%$ of all pediatric intensive care unit (PICU) admissions with an International Classification of Diseases (ICD)-10 code for pathogen-specific sepsis in children below the age of 17 years in Switzerland (Supplementary Table 1). The ten study centers host all tertiary neonatal intensive care units (NICU) of the country and comprise all tertiary pediatric oncology and pediatric surgery services.

We obtained written informed consent from patients, or their legal guardians before study enrollment. In patients who fulfilled inclusion criteria but consent was not available, waiver from informed consent had been granted by the ethics commission for collection of anonymized clinical data. The study was approved by the ethics committees of all participating centers (Cantonal Ethics Committee, Inselspital, University of Bern, no. KEK- 029/11).

\section{Study population and Definitions}

All neonates and children $<17$ years of age with blood culture-proven invasive bacterial or fungal infection and SIRS, as defined by 2005 consensus definitions, ${ }^{2}$ were eligible if they met SIRS criteria at the time of blood culture sampling. Blood cultures were processed according to the standard operating procedures of the local microbiological laboratories. At each study site, the clinician in charge of patient enrollment was notified by the microbiology laboratory using an automated alert process. We excluded children if blood culture isolates were considered to be contaminants (Supplementary Methods). Additionally, we excluded children after allogeneic bone marrow transplantation. SIRS criteria were assessed prospectively by clinicians. Data on demographics, perinatal and other risk factors, comorbidities, infection site, severity, and outcome were entered prospectively into an online database. Data monitoring and quality controls were performed by the local Clinical Trial Units under the guidance of SwissPedNet, a coordination platform for pediatric clinical research in Switzerland and member of the Swiss Clinical Trial Organization (www.scto.ch). We defined organ dysfunctions (cardiovascular, 
Author Manuscript Published in final edited form as: Lancet Child Adolesc Health. 2017 Oct;1(2):124-133 DOI: http://dx.doi.org/10.1016/S2352-4642(17)30010-X

respiratory, hepatic, renal, neurologic, hematologic) according to the 2005 consensus definitions; ${ }^{2}$ organ dysfunctions were recorded from the time of blood culture sampling on. 30-day in-hospital mortality was the primary outcome. We defined a priori three patient groups: i) Previously healthy children, including term born infants $\geq 28$ days of age; ii) Neonates, including term born neonates $<28$ days of age and prematurely born neonates $<44$ weeks postconceptional age at sepsis onset; and iii) Children $\geq 28$ days of age with comorbidities, such as chronic inborn or acquired medical conditions, recent surgery or burns. Comorbidities were categorized according to the pediatric complex chronic conditions classification system version $2 .{ }^{16}$ Hospital-acquired infection (i.e., blood culture obtained $>48 \mathrm{~h}$ after admission) and central line-associated bloodstream infection (CLABSI) were defined according to the CDC criteria. ${ }^{17}$

\section{Incidence calculation}

To calculate incidence rates of blood culture-proven bacterial sepsis, we included only sepsis episodes recorded in full study years, between January 1, 2012, and December 31, 2015 $(\mathrm{n}=1126)$. To calculate age-specific incidence rates, we divided the number of annual sepsis episodes in the study by the end of year resident population in Switzerland in the respective age groups. Incidence rates were calculated for different age groups and age-standardized to the European standard population. ${ }^{18}$ We estimated national incidence rates of blood culture-proven bacterial sepsis based on mandatory hospital statistics of Swiss children $<17$ years with an ICD10 code for sepsis associated to a specific pathogen (Supplementary Methods and Supplementary Table 1).

\section{Statistics}

Descriptive statistics are presented as median and interquartile ranges (IQR) for continuous variables and frequencies and percentages for categorical variables. We used $\chi^{2}$ test of proportions and the Wilcoxon non-parametric rank sum test to compare covariates between children >28days with one or multiple comorbidities. Post-hoc Bonferroni correction was applied.

We fitted multilevel binomial regression models for potential determinants (patient group, number of organ dysfunctions, and gender) of death within the first 30 days after sepsis onset with the presence of organ dysfunctions using a random effect to correct for correlation between multiple observations at the same hospital. For this analysis we included only the first sepsis episode of each patient ( $\mathrm{n}=1096)$, to avoid conditionality between repeat sepsis events in the same patient. We separately fitted univariable models for the patient group, the number of organ 
Author Manuscript Published in final edited form as: Lancet Child Adolesc Health. 2017 Oct;1(2):124-133 DOI: http://dx.doi.org/10.1016/S2352-4642(17)30010-X

dysfunctions present (such as any organ dysfunction, two and more organ dysfunctions, three and more organ dysfunctions), and gender. Then we fitted multivariable (adjusted) models containing all potential risk factors. We used backward stepwise selection with likelihood ratio tests to eliminate covariates with $\mathrm{p}>0.1$ from the adjusted models. The best fitted model included the patient group and the presence of any organ dysfunction, two and more organ dysfunctions, four and more organ dysfunctions, and six organ dysfunctions. Due to the low number of observations with more than 4 organ dysfunctions, in the final selected model we adjusted for patient group and organ dysfunctions, categorized into no organ dysfunction, one organ dysfunction, two or three organ dysfunctions, and four or more organ dysfunctions. Corresponding area under the receiver operating characteristic curve (AUROC) was used to evaluate the performance of the model in assessing the risk for 30-day in-hospital mortality. Results of binomial multilevel regression analysis are presented as odds ratio (OR) with $95 \%$ confidence interval (CI) and pvalue. We considered a 2-sided p-value of $<0.05$ as significant. All analyses and plots were done using R version 3.4.0 (R Core Team (2016). R: A language and environment for statistical computing. R Foundation for Statistical Computing, Vienna, Austria. URL https://www.Rproject.org/).

\section{Role of the funding source}

The sponsor of the study had no role in the study design, data collection, data analysis, data interpretation, or writing of the report. The corresponding authors had full access to all the data in the study and had final responsibility for the decision to submit for publication. 
Author Manuscript Published in final edited form as: Lancet Child Adolesc Health. 2017 Oct;1(2):124-133 DOI: http://dx.doi.org/10.1016/S2352-4642(17)30010-X

\section{Results}

We prospectively recorded 1204 eligible blood culture-proven sepsis episodes in 1110 children during the 52 months of the study (Figure 1). Twenty-three (2\%) episodes with fungal septicemia were excluded for this analysis. Of the remaining 1181 blood culture-proven bacterial sepsis episodes, 382 (32\%) occurred in previously healthy children, 402 (34\%) in neonates, and 397 (34\%) in children with comorbidities (Table 1). Seventy-nine (7\%) children experienced two or more sepsis episodes (median 2, range 2-7).

\section{Incidence}

The crude annual incidence of blood culture-proven bacterial sepsis per 100'000 children was $19 \cdot 1$ (95\%-CI $18 \cdot 0-20 \cdot 3)$, corresponding to an age-standardized incidence of 20 1 per 100 '000 children (95\%-CI 18·9-21·2). The estimated national age-standardized incidence of blood culture-proven bacterial sepsis was $25 \cdot 1$ per $100^{\prime} 000$ children per year (95\%-CI $\left.23 \cdot 8-26 \cdot 4\right)$. The national incidence of blood culture-proven bacterial sepsis was strongly age-dependent, with highest estimates in neonates (146. 0 per 100'000 neonates; 95\%-CI 133.2-159.6), and infants (85.3 per 100'000 infants; 95\%-CI 75.6-95.9) (Figure 2). The estimated national agestandardized incidence of blood culture-proven bacterial sepsis with any organ dysfunction was $8 \cdot 3$ per 100 '000 children per year (95\%-CI 7.5-9.1) (Figure 2).

\section{Site of infection and pathogens}

CLABSI and primary bloodstream infection were the most frequent sites of infection in the entire cohort (327/1181, 28\% and 242/1181, 20\%, respectively), in neonates $(125 / 402,31 \%$ and $146 / 402,36 \%$, respectively), and in children with comorbidities (202/397, 51\% and 47/397, $12 \%$, respectively) (Table 2). CLABSI-associated sepsis was primarily hospital-acquired (227/327, $69 \%$ ). A distinct site of infection was identified in 333/382 (87\%) previously healthy children (Table 2), frequently associated to a particular pathogen (Supplementary Figure S1). E. coli $(242 / 1181,20 \%)$, S. aureus $(177 / 1181,15 \%)$, coagulase negative staphylococci $(135 / 1181,11 \%)$, and S. pneumoniae $(118 / 1181,10 \%)$ were the most prevalent pathogens in our study, accounting for $57 \%$ of episodes (Table 2). The distribution of infection sites and pathogens showed major differences pertinent to the three patient groups and age (Figure 3). In 36/1181 (3\%) episodes multi-resistant bacteria were cultured, including extended-spectrum beta-lactamase resistant bacteria in 23/1181 (2\%), methicillin-resistant S. aureus in 8/1181 (1\%), and carbapenemase resistant bacteria in 5/1181 (0\%). 
Author Manuscript Published in final edited form as: Lancet Child Adolesc Health. 2017 Oct;1(2):124-133 DOI: http://dx.doi.org/10.1016/S2352-4642(17)30010-X

\section{Severity and outcome of sepsis}

In 570/1181 (48\%) episodes, children were treated in PICU or NICU, including 271/1181 (23\%) episodes were children required intensive care admission because of blood culture-proven bacterial sepsis (Table 3). In 455/1181 (39\%) episodes an organ dysfunction was present. Respiratory dysfunction $(348 / 1181,29 \%)$ and cardiovascular dysfunction $(215 / 1181,18 \%)$ were the most prevalent organ dysfunctions recorded (Supplementary Table S2), with inotropes required in 177/1181 (15\%) episodes and new invasive ventilation required in 201/1181 (17\%) episodes (Table 3).

Eighty-two children died within the first 30 days after the time of blood culture sampling, resulting in a case fatality ratio (CFR) of 7\% (95\%-CI 5.6-8.6) with a median time to death of 2 days (IQR 1-7) (Table 3). The CFR was lower in previously healthy children (10/382, 3\% (95\%CI 1.3-4.9)) than in neonates (45/402, $11 \%$ (95\%-CI 8.4-14.8)) and in children with comorbidities (27/397, 7\% (95\%-CI 4.6-9.9)) (Table 3). This was confirmed in regression analysis with an adjusted OR for death in neonates of 4.41 (95\%-CI 1.75-11.1) and 4.97 (95\%CI 1.84-13.4)) in children with comorbidities compared to previously healthy children (Table 4 and Supplementary Table S3). In children with comorbidities, those with multiple comorbidities were more often treated in PICU than children with a single comorbidity (57/103, 55\% vs. $82 / 294,28 \%, \mathrm{p}<0 \cdot 0001)$, more often required respiratory support $(35 / 103,34 \%$ vs. $35 / 294$, $12 \%, \mathrm{p}<0.0001)$, and inotropes $(29 / 103,28 \%$ vs. $36 / 294,12 \%, \mathrm{p}=0.005)$, and had a longer length of stay after sepsis onset (20 days (IQR 12-57) vs. 13 days (IQR 7-24), p = 0.0009), while the CFR was not different $(10 / 103,10 \%$ vs. $17 / 294,6 \%, p=1 \cdot 0)$ (Supplementary Table S4). The CFR was lower in children with no organ dysfunction (5/726, $1 \%$ (95\%-CI 0-3-1·7)) compared to those with at least one organ dysfunction (77/455, 17\% (95\%-CI 13·7-20.8)). The CFR increased with rising number of organ dysfunctions present (Figure 4, Supplementary Table S2, and Supplementary Figure S2).

In adjusted regression analyses, the CFR increased in the presence of one (OR 4.97 (95\%-CI 1.43-17-2)), two or three (OR 49.5 (95\%-CI 16.1-152)), and four or more organ dysfunctions (OR 275 (95\%-CI 78.6-962)) (Table 4 and Supplementary Table S3). The model performed well to identify children with fatal outcome (AUROC $0 \cdot 92,95 \%$-CI 0.89-0.92). 
Author Manuscript Published in final edited form as: Lancet Child Adolesc Health. 2017 Oct;1(2):124-133 DOI: http://dx.doi.org/10.1016/S2352-4642(17)30010-X

\section{Discussion}

In this prospective, population-based study in a high-income country, the age-standardized incidence of pediatric blood culture-proven bacterial sepsis, as defined by 2005 consensus criteria $^{2}{ }^{\text {was }} 25 \cdot 1$ per 100 '000 children per year with an average 30-day in-hospital mortality of $7 \%$ (95\%-CI 5-6-8.6). We observed major differences in clinical presentation, causative pathogen, disease severity, and outcome of sepsis between previously healthy children, neonates, and children with comorbidities. While the majority of blood culture-proven bacterial sepsis episodes had no organ dysfunction which was associated with a CFR of $<1 \%$, presence and number of organ dysfunctions strongly increased 30-day in-hospital mortality.

To the best of our knowledge, this is the largest population-based prospective study capturing blood culture-proven bacterial sepsis in all neonatal and pediatric age groups with detailed characterization of clinical host phenotypes. Our study fills an important knowledge gap, given that the majority of previous studies on sepsis in children included up to $50 \%$ of patients with suspected infections, lacking comprehensive microbiological diagnostics or including microbiological results that may represent colonization or viral infection. ${ }^{19,20}$ In comparison, pathogen-specific sepsis, as captured by our study, accounted for 66\% (1190/1813) of pediatric hospital admissions coded as sepsis in 2012-2015 in the ten study centers, in comparison to 56\% (1534/2736) when assessing all pediatric hospital admissions in Switzerland using ICD-10 discharge coding (Supplementary Table 1). In agreement with a US and European study on bloodstream infections in adults, ${ }^{5}$ our findings indicate that confirmed blood culture-proven bacterial sepsis represents a more severe infection phenotype, associated with significantly higher mortality compared to other studies based on clinical definitions of sepsis. ${ }^{19}$

Based on our data, 4\% (95\%-CI 3·5-5.4) of all childhood deaths in the years 2012 to 2015 in Switzerland $^{21}$ were associated with blood culture-proven bacterial sepsis, with blood cultureproven bacterial sepsis ranking 5th of all childhood death causes. This is lower than reported in previous studies in Finland, ${ }^{22}$ a country with a very low childhood mortality, and Wales, ${ }^{23}$ however, these were based on coding for any infectious cause using death registrations. While bloodstream infections are likely to be underreported in hospital coding-based reports as patients may be coded according to the underlying focus of infection, our study was based on prospective screening by pediatric infectious disease teams and automated microbiology laboratory reporting. 
Author Manuscript Published in final edited form as: Lancet Child Adolesc Health. 2017 Oct;1(2):124-133 DOI: http://dx.doi.org/10.1016/S2352-4642(17)30010-X

Our study demonstrates the importance of organ dysfunction to identify patient groups at substantially higher mortality risk, which can inform the translation of Sepsis- $3^{13}$ into future pediatric sepsis definitions. The current definition for pediatric sepsis and sepsis severity is based on the 2005 consensus statement, requiring the presence of suspected infection and SIRS ${ }^{2}$. Approximately two-thirds $(61 \%, 95 \%$-CI (58.6-64-2)) of bacteremia episodes in our cohort were classified as sepsis, despite the absence of organ failure, with close to zero mortality. Presence of SIRS in these cases may indeed represent an appropriate rather than dysregulated host response to infection. ${ }^{14}$ In contrast, the recent Sepsis- 3 consensus definition in adults discriminates sepsis from uncomplicated infection by the presence of organ dysfunction. ${ }^{13}$ Our findings demonstrate that the majority of pediatric invasive bacterial infections respond to appropriate antimicrobial treatment without the development of organ dysfunction, confirming that timely recognition of infection and initiation of antibiotics remain the most important cornerstones of treatment. ${ }^{24}$ In contrast, in approximately a third (39\%, 95\%-CI (35.8-41-4)) of sepsis episodes in our study new or worsening organ failure was present, associated with a dramatic increase in mortality to $17 \%$ (95\%-CI 13.7-20.8) if at least one organ dysfunction was present, to $29 \%(95 \%$-CI $22 \cdot 9-34 \cdot 9)$ if two or more organ dysfunctions were present. Our findings are supported by a recent international pediatric point prevalence study including 567 children with severe sepsis in 128 PICUs, which reported a mortality increase from $10 \%$ in children with single organ dysfunction to $28 \%$ in children with new multiple organ dysfunction syndrome, and a concomitant threefold increase in moderate to severe disability in survivors. ${ }^{25}$ Importantly, while the 2005 consensus definitions $^{2}$ weighted cardiovascular failure higher than other organ dysfunctions (Supplementary Figure S3), our findings indicate that substantial mortality increase is seen in all types of organ failure. Future studies should investigate mechanisms, predictors, and markers to early identify which children are at risk for severe organ dysfunction as a result of dysregulated host response. In agreement with previous reports, ${ }^{7,8}$ we observed that $57 \%$ of blood culture-proven bacterial sepsis deaths occurred within 48 hours of presentation, which has important implications for the design of interventional studies attempting to reduce sepsis mortality in children.

Our study provides insight into prevailing patterns and organisms for community-acquired and hospital-acquired sepsis. The incidence of sepsis in our study was highest in neonates, with approximately 1 per 1000 developing blood culture-proven bacterial sepsis. 54\% of all sepsis episodes in our study occurred in neonates and infants, and $74 \%$ in children below five years of age, likely mirroring the maturation of the innate and adaptive immune system during the first 
Author Manuscript Published in final edited form as: Lancet Child Adolesc Health. 2017 Oct;1(2):124-133 DOI: http://dx.doi.org/10.1016/S2352-4642(17)30010-X

years of life. Despite the decline in invasive pneumococcal infections since the introduction of pneumococcal vaccination in Switzerland in 2006, the majority of sepsis cases in previously healthy children were caused by S. pneumoniae. Of note, few sepsis cases were due to $N$. meningitidis, in contrast to other cohorts where $N$. meningitidis was one of the most predominant organisms. S. aureus was the second most common pathogen for community-acquired sepsis in previously healthy children, with an estimated age-standardized incidence of 3.7 per 100 '000 (95\%-CI $3 \cdot 2-4 \cdot 2)$. In comparison, the recent Australian New Zealand Cooperative on Outcomes in Staphylococcal Sepsis study reported an incidence of $8 \cdot 3$ per 100000 population with a mortality of $4.7 \% .^{26}$

Approximately one-third of all blood culture-proven bacterial sepsis episodes in our study occurred in previously healthy children, frequently presenting with age-specific combinations of pathogens and sites of infection. The associated severity in previously healthy children was considerable, as $28 \%$ required PICU admission with a CFR of $8 \%$ (95\%-CI 4\%-16\%). Underlying unrecognized primary immunodeficiencies, and other genetic and non-genetic host factors conferring increased susceptibility to fulminant sepsis have been shown to account for a proportion of severe infections in previously healthy children, but further studies are needed to elucidate the underlying host and pathogen interactions. ${ }^{27,28}$ In addition our results indicate an urgent need for improved preventive strategies, including measures against E. coli and S. aureus infections which are responsible for an increasing proportion of sepsis cases given the decline in vaccine-preventable infections. In contrast, the majority of blood culture-proven bacterial sepsis episodes in neonates and children with comorbidities in our study were hospital-acquired or health-care associated, with CLABSI accounting for 53\% of hospital-acquired sepsis. This is of particular relevance as most healthcare-associated infections have to be considered in principle preventable, ${ }^{29}$ indicating an urgent need for improved bundle implementation, bundle maintenance, and benchmarking. ${ }^{30}$

Several limitations of this study have to be considered. First, while we included all the main pediatric hospitals in Switzerland, including all PICUs, NICUs, tertiary pediatric surgery, and oncology centers to estimate the population-based burden of disease, this may have led to a bias towards sepsis of greater severity, and sepsis in children with comorbidities, such as premature neonates and oncology patients. Second, geography, demography, epidemiology, and the organization of the healthcare system in Switzerland have to be considered, when attempting to generalize our findings. Third, we did not prospectively collect daily data on Sequential Organ 
Author Manuscript Published in final edited form as: Lancet Child Adolesc Health. 2017 Oct;1(2):124-133 DOI: http://dx.doi.org/10.1016/S2352-4642(17)30010-X

Failure Assessment Scores, ${ }^{13}$ which have not been validated for children, and the timing of progression towards organ failure was not assessed. Fourth, the inclusion criteria required presence of blood-culture-proven sepsis as per 2005 consensus criteria, ${ }^{2}$ and the study was therefore not designed to analyze contaminations and blood culture-proven infection in children without SIRS. Fifth, we defined 30-day mortality as main outcome, whereas longterm neurodevelopmental outcome and quality of health in sepsis survivors were not assessed. Sixth, our study excluded allogeneic bone marrow transplants which may have led to an underestimation of the incidence. Finally, despite the size of the study, the number of deaths was relatively low, limiting more extensive subgroup analyses when adjusting statistical models for potential covariates.

In conclusion, this contemporary population-based cohort on pediatric blood culture-proven bacterial sepsis observed an ongoing burden of disease in a high-income country. The findings demonstrate distinct patterns in relation to epidemiology, host susceptibility, pathogen spectrum, and outcomes of pediatric sepsis. While the majority of bacteremia episodes had no organ dysfunction with close to zero mortality, we demonstrated the importance of organ dysfunction to characterize patients with substantially worse outcomes, which should be considered when reviewing pediatric sepsis definitions. These data may serve to inform current antimicrobial strategies and future sepsis trials and to identify high-risk populations most likely to benefit from targeted preventive and therapeutic interventions.

(C) 2017. This manuscript version is made available under the CC-BY-NC-ND 4.0 license http://creativecommons.org/licenses/by-nc-nd/4.0/ 
Author Manuscript Published in final edited form as: Lancet Child Adolesc Health. 2017 Oct;1(2):124-133 DOI: http://dx.doi.org/10.1016/S2352-4642(17)30010-X

\section{Panel: Research in context}

Evidence before this study: We searched PubMed for studies published in English, reporting longitudinal population-based data for incidence and mortality of bacteremia and sepsis in children < 17 years published between 1990 and 2016. We used the search terms "bacteremia", "blood culture", "bloodstream infection", "mortality", "sepsis", “child”, and "epidemiology". Invasive bacterial infections represent one of the leading causes of childhood mortality worldwide, and contribute to $11-20 \%$ of childhood deaths in high-income countries. The incidence of invasive infections is highest in neonates and children, yet there is a lack of population-based analyses on microbiologically confirmed severe bacterial infections in childhood. In addition to age, host factors such as underlying disease are primary determinants of susceptibility and outcomes. A limitation of larger studies on childhood sepsis consists in the use of clinical definitions of sepsis, with only a minority of sepsis episodes being microbiologically confirmed, and lack of robust characterization of comorbidities. Considering the detrimental effect of delays in antimicrobial treatment in bacterial sepsis, representative data on the contemporary burden of bacterial sepsis are urgently needed to guide national strategies for optimal antibiotic usage. Added value: We report specific patterns of clinical presentation, causative pathogen, disease severity, and outcome of sepsis which differed significantly between previously healthy children, neonates, and children with comorbidities. While the majority of bacteremia episodes had no organ dysfunction with close to zero mortality, presence and number of organ dysfunctions were strongly associated with mortality. Implications of all the available evidence: We demonstrate an ongoing high burden of pediatric bacterial sepsis and identify highrisk groups most likely to benefit from targeted preventive and therapeutic interventions, which can inform current management strategies and future sepsis trials, in particular in view of the next iteration of pediatric Surviving Sepsis Guidelines and pediatric-specific sepsis definitions. 
Author Manuscript Published in final edited form as: Lancet Child Adolesc Health. 2017 Oct;1(2):124-133 DOI: http://dx.doi.org/10.1016/S2352-4642(17)30010-X

\section{Authors and Contributions}

The corresponding authors, Dr. Agyeman and Dr. Schlapbach, had full access to all the data in the study and had final responsibility for the decision to submit for publication. Dr. Agyeman, Dr. Schlapbach, and Dr. Berger were responsible for the study design, prepared the first manuscript draft and approved the final version. Dr. Kuehni and Dr. Schindler performed population-based analyses, revised the manuscript, and approved the final version. Dr. Korten and Dr. Agyeman performed statistical analysis. Dr. Aebi was supervising the study and involved in study design, analyses, manuscript preparation, and approval of the final version. Drs Posfay-Barbe, Giannoni, Stocker, Heininger, Konetzny, Hasters, Leone, Relly, Baer, Niederer-Loher, and Kahlert were involved in study design, patient recruitment, data analysis, and manuscript preparation, and approved the final version.

\section{Declaration of interests}

None of the coauthors declared a conflict of interest.

\section{Role of funding source}

This study was funded by grants from the Swiss National Science Foundation (342730_153158/1), the Swiss Society of Intensive Care, the Bangerter Foundation, the Vinetum and Borer Foundation, and the Foundation for the Health of Children and Adolescents. The funding sources had no involvement in the design, analysis, and writing of the present manuscript.

\section{Acknowledgements}

The authors would like to thank in particular the participating patients and their families. In addition, the authors would like to thank B. Spycher for assistance with statistical analysis, the study nurses at each study site, and PedNet. 
Author Manuscript Published in final edited form as: Lancet Child Adolesc Health. 2017

Oct;1(2):124-133 DOI: http://dx.doi.org/10.1016/S2352-4642(17)30010-X

\section{Funding}

This study was funded by grants from the Swiss National Science Foundation

(342730_153158/1), the Swiss Society of Intensive Care, the Bangerter Foundation, the Vinetum and Borer Foundation, and the Foundation for the Health of Children and Adolescents.

(C) 2017. This manuscript version is made available under the CC-BY-NC-ND 4.0 license http://creativecommons.org/licenses/by-nc-nd/4.0/ 
Author Manuscript Published in final edited form as: Lancet Child Adolesc Health. 2017 Oct;1(2):124-133 DOI: http://dx.doi.org/10.1016/S2352-4642(17)30010-X

\section{References}

1 Dellinger RP, Levy MM, Rhodes A et al. Surviving Sepsis Campaign: International guidelines for management of severe sepsis and septic shock, 2012. Intensive Care Medicine 2013; 39: $165-228$.

2 Goldstein B, Giroir B, Randolph A, International Consensus Conference on Pediatric Sepsis. International pediatric sepsis consensus conference: Definitions for sepsis and organ dysfunction in pediatrics. Pediatric Critical Care Medicine: A Journal of the Society of Critical Care Medicine and the World Federation of Pediatric Intensive and Critical Care Societies 2005; 6: 2-8.

3 Hartman ME, Linde-Zwirble WT, Angus DC, Watson RS. Trends in the epidemiology of pediatric severe sepsis*. Pediatric Critical Care Medicine: A Journal of the Society of Critical Care Medicine and the World Federation of Pediatric Intensive and Critical Care Societies 2013; 14: 686-93.

4 Ruth A, McCracken CE, Fortenberry JD, Hall M, Simon HK, Hebbar KB. Pediatric severe sepsis: Current trends and outcomes from the Pediatric Health Information Systems database. Pediatric Critical Care Medicine: A Journal of the Society of Critical Care Medicine and the World Federation of Pediatric Intensive and Critical Care Societies 2014; 15: 828-38.

5 Goto M, Al-Hasan MN. Overall burden of bloodstream infection and nosocomial bloodstream infection in North America and Europe. Clinical Microbiology and Infection: The Official Publication of the European Society of Clinical Microbiology and Infectious Diseases 2013; 19: $501-9$.

6 Laupland KB. Incidence of bloodstream infection: A review of population-based studies. Clinical Microbiology and Infection: The Official Publication of the European Society of Clinical Microbiology and Infectious Diseases 2013; 19: 492-500.

7 Cvetkovic M, Lutman D, Ramnarayan P, Pathan N, Inwald DP, Peters MJ. Timing of death in children referred for intensive care with severe sepsis: Implications for interventional studies. Pediatric Critical Care Medicine: A Journal of the Society of Critical Care Medicine and the World Federation of Pediatric Intensive and Critical Care Societies 2015; 16: 410-7.

8 Schlapbach LJ, MacLaren G, Festa M et al. Prediction of pediatric sepsis mortality within $1 \mathrm{~h}$ of intensive care admission. Intensive Care Medicine 2017; published online Feb. DOI:10.1007/s00134-017-4701-8.

(C) 2017. This manuscript version is made available under the CC-BY-NC-ND 4.0 license http://creativecommons.org/licenses/by-nc-nd/4.0/ 
Author Manuscript Published in final edited form as: Lancet Child Adolesc Health. 2017 Oct;1(2):124-133 DOI: http://dx.doi.org/10.1016/S2352-4642(17)30010-X

9 Henderson KL, Johnson AP, Muller-Pebody B, Charlett A, Gilbert R, Sharland M. The changing aetiology of paediatric bacteraemia in England and Wales, 1998-2007. Journal of Medical Microbiology 2010; 59: 213-9.

10 Levy MM, Artigas A, Phillips GS et al. Outcomes of the Surviving Sepsis Campaign in intensive care units in the USA and Europe: A prospective cohort study. The Lancet Infectious Diseases 2012; 12: 919-24.

11 Weiss SL, Fitzgerald JC, Balamuth F et al. Delayed antimicrobial therapy increases mortality and organ dysfunction duration in pediatric sepsis. Critical Care Medicine 2014; 42: 2409-17.

12 NICE antimicrobial stewardship: Right drug, dose, and time? Lancet (London, England) 2015; 386: 717.

13 Singer M, Deutschman CS, Seymour CW et al. The Third International Consensus Definitions for Sepsis and Septic Shock (Sepsis-3). JAMA 2016; 315: 801-10.

14 Vincent J-L, Opal SM, Marshall JC, Tracey KJ. Sepsis definitions: Time for change. Lancet (London, England) 2013; 381: 774-5.

15 Giannoni E, Berger C, Stocker M et al. Incidence and Outcome of Group B Streptococcal Sepsis in Infants in Switzerland. The Pediatric Infectious Disease Journal 2016; 35: $222-4$.

16 Feudtner C, Feinstein JA, Zhong W, Hall M, Dai D. Pediatric complex chronic conditions classification system version 2: Updated for ICD-10 and complex medical technology dependence and transplantation. BMC pediatrics 2014; 14: 199.

17 Centers for Disease Control and Prevention. Surveillance for Bloodstream Infections. ACH Surveillance for BSI (CLABSI) NHSN CDC. 2016. https://www.cdc.gov/nhsn/acute-carehospital/clabsi/index.html (accessed May 23, 2016).

18 Waterhouse J, Muir C, Correa P, Powell J, editors. Cancer incidence in five continents. Lyon: IARC, 1976.

19 Schlapbach LJ, Straney L, Alexander J et al. Mortality related to invasive infections, sepsis, and septic shock in critically ill children in Australia and New Zealand, 2002-13: A multicentre retrospective cohort study. The Lancet Infectious Diseases 2015; 15: 46-54.

20 Weiss SL, Fitzgerald JC, Pappachan J et al. Global epidemiology of pediatric severe sepsis: The sepsis prevalence, outcomes, and therapies study. American Journal of Respiratory and Critical Care Medicine 2015; 191: 1147-57.

21 Federal Statistical Office Switzerland. Todesfälle nach Geschlecht, Staatsangehörigkeit, Zivilstand und Alter. 2016; published online June.

(C) 2017. This manuscript version is made available under the CC-BY-NC-ND 4.0 license http://creativecommons.org/licenses/by-nc-nd/4.0/ 
Author Manuscript Published in final edited form as: Lancet Child Adolesc Health. 2017 Oct;1(2):124-133 DOI: http://dx.doi.org/10.1016/S2352-4642(17)30010-X

\section{https://www.bfs.admin.ch/bfs/de/home/statistiken/bevoelkerung/geburten-}

todesfaelle/todesfaelle-sterblichkeit-lebenserwartung.assetdetail.325569.html (accessed Feb 21, 2017).

22 Lantto M, Renko M, Uhari M. Changes in infectious disease mortality in children during the past three decades. The Pediatric Infectious Disease Journal 2013; 32: e355-359.

23 Ladhani S, Pebody RG, Ramsay ME, Lamagni TL, Johnson AP, Sharland M. Continuing impact of infectious diseases on childhood deaths in England and Wales, 2003-2005. The Pediatric Infectious Disease Journal 2010; 29: 310-3.

24 Launay E, Gras-Le Guen C, Martinot A et al. Why children with severe bacterial infection die: A population-based study of determinants and consequences of suboptimal care with a special emphasis on methodological issues. PloS One 2014; 9: e107286.

25 Lin JC, Spinella PC, Fitzgerald JC et al. New or Progressive Multiple Organ Dysfunction Syndrome in Pediatric Severe Sepsis: A Sepsis Phenotype With Higher Morbidity and Mortality. Pediatric Critical Care Medicine: A Journal of the Society of Critical Care Medicine and the World Federation of Pediatric Intensive and Critical Care Societies 2017; 18: $8-16$.

26 McMullan BJ, Bowen A, Blyth CC et al. Epidemiology and Mortality of Staphylococcus aureus Bacteremia in Australian and New Zealand Children. JAMA pediatrics 2016; 170: 97986.

27 Davila S, Wright VJ, Khor CC et al. Genome-wide association study identifies variants in the $\mathrm{CFH}$ region associated with host susceptibility to meningococcal disease. Nature Genetics 2010; 42: 772-6.

28 Asgari S, McLaren PJ, Peake J et al. Exome Sequencing Reveals Primary Immunodeficiencies in Children with Community-Acquired Pseudomonas aeruginosa Sepsis. Frontiers in Immunology 2016; 7: 357.

29 Zingg W, Holmes A, Dettenkofer M et al. Hospital organisation, management, and structure for prevention of health-care-associated infection: A systematic review and expert consensus. The Lancet Infectious Diseases 2015; 15: 212-24.

30 Gilbert RE, Mok Q, Dwan K et al. Impregnated central venous catheters for prevention of bloodstream infection in children (the CATCH trial): A randomised controlled trial. Lancet (London, England) 2016; 387: 1732-42. 
Author Manuscript Published in final edited form as: Lancet Child Adolesc Health. 2017 Oct;1(2):124-133 DOI: http://dx.doi.org/10.1016/S2352-4642(17)30010-X

\section{Tables}

\section{Table 1 - Demographic and clinical characteristics of neonates and children with blood culture-proven bacterial sepsis}

\begin{tabular}{|c|c|c|c|c|}
\hline & $\begin{array}{l}\text { All episodes } \\
(\mathrm{n}=1181 \text {, in } 1096 \\
\text { children })\end{array}$ & $\begin{array}{l}\text { Episodes in } \\
\text { previously healthy } \\
\text { children } \\
\text { ( } \mathrm{n}=382 \text {, in } 379 \\
\text { children) }\end{array}$ & $\begin{array}{l}\text { Episodes in } \\
\text { neonates } \\
\text { ( } \mathrm{n}=402 \text {, in } 391 \\
\text { infants) }\end{array}$ & $\begin{array}{l}\text { Episodes in } \\
\text { children with } \\
\text { comorbidities } \\
\text { ( } \mathrm{n}=397 \text {, in } 341 \\
\text { children) }\end{array}$ \\
\hline \multicolumn{5}{|l|}{ Demographics } \\
\hline Age at sepsis onset (months) & $7 \cdot 6(0 \cdot 6-63 \cdot 6)$ & $44 \cdot 3(6-108 \cdot 2)$ & $0 \cdot 3(0 \cdot 2-0 \cdot 7)$ & $37 \cdot 4(9 \cdot 7-98 \cdot 7)$ \\
\hline \multicolumn{5}{|l|}{ Age groups } \\
\hline $\begin{array}{l}\text { Preterm newborn }<44 \text { weeks } \\
\text { postconceptional age }\end{array}$ & $266(22 \cdot 5 \%)$ & & $266(66 \cdot 2 \%)$ & \\
\hline Term newborn $<28$ days & $136(11 \cdot 5 \%)$ & & $136(33 \cdot 8 \%)$ & \\
\hline 28-365 days & $237(20 \cdot 1 \%)$ & $126(33 \cdot 0 \%)$ & & $111(28 \cdot 0 \%)$ \\
\hline $1-4$ years & $235(19 \cdot 9 \%)$ & $96(25 \cdot 1 \%)$ & & $139(35 \cdot 0 \%)$ \\
\hline $5-9$ years & $148(12 \cdot 5 \%)$ & $76(19 \cdot 9 \%)$ & & $72(18 \cdot 1 \%)$ \\
\hline $10-16$ years & $159(13 \cdot 5 \%)$ & $84(22.0 \%)$ & & $75(18 \cdot 9 \%)$ \\
\hline Male & $705(59 \cdot 7 \%)$ & $220(57 \cdot 6 \%)$ & $254(63 \cdot 2 \%)$ & $231(58 \cdot 2 \%)$ \\
\hline \multicolumn{5}{|l|}{ Ethnicity $^{\mathrm{a}}$} \\
\hline Caucasian & $915(85 \cdot 1 \%)$ & $300(89 \cdot 6 \%)$ & $313(87 \cdot 2 \%)$ & $302(79 \cdot 3 \%)$ \\
\hline Asian & $39(3 \cdot 6 \%)$ & $12(3 \cdot 6 \%)$ & $6(1.7 \%)$ & $21(5 \cdot 5 \%)$ \\
\hline African & $49(4 \cdot 6 \%)$ & $13(3 \cdot 9 \%)$ & $9(2.5 \%)$ & $27(7 \cdot 1 \%)$ \\
\hline other & $72(6 \cdot 7 \%)$ & $10(3 \cdot 0 \%)$ & $9(2 \cdot 5 \%)$ & $31(8 \cdot 1 \%)$ \\
\hline \multicolumn{5}{|l|}{$\begin{array}{l}\text { Clinical characteristics } \\
\text { Comorbidities }^{\mathrm{b}}\end{array}$} \\
\hline $\begin{array}{l}\text { Neurologic and } \\
\text { neuromuscular }\end{array}$ & $41(3 \cdot 5 \%)$ & & $10(2 \cdot 5 \%)$ & $31(7 \cdot 8 \%)$ \\
\hline Cardiovascular & $90(7 \cdot 6 \%)$ & & $20(5 \cdot 0 \%)$ & $70(17 \cdot 6 \%)$ \\
\hline Respiratory & $56(4 \cdot 7 \%)$ & & $16(4 \cdot 0 \%)$ & $40(10 \cdot 1 \%)$ \\
\hline Renal and urologic & $46(3 \cdot 9 \%)$ & & $8(2 \cdot 0 \%)$ & $38(9 \cdot 6 \%)$ \\
\hline Gastrointestinal & $92(7 \cdot 8 \%)$ & & $17(4 \cdot 2 \%)$ & $75(18 \cdot 9 \%)$ \\
\hline \multicolumn{5}{|l|}{ Haematologic or } \\
\hline Immunologic & $18(1.5 \%)$ & & $0(0 \%)$ & $18(4 \cdot 5 \%)$ \\
\hline Metabolic & $18(1.5 \%)$ & & $5(1 \cdot 2 \%)$ & $13(3 \cdot 3 \%)$ \\
\hline $\begin{array}{l}\text { Other congenital or genetic } \\
\text { defect }\end{array}$ & \multicolumn{3}{|c|}{ Other congenital or genetic } & $25(6 \cdot 3 \%)$ \\
\hline
\end{tabular}

(C) 2017. This manuscript version is made available under the CC-BY-NC-ND 4.0 license http://creativecommons.org/licenses/by-nc-nd/4.0/ 
Author Manuscript Published in final edited form as: Lancet Child Adolesc Health. 2017 Oct;1(2):124-133 DOI: http://dx.doi.org/10.1016/S2352-4642(17)30010-X

\begin{tabular}{|c|c|c|c|c|}
\hline Malignancy & \multicolumn{2}{|l|}{$144(12 \cdot 2 \%)$} & $0(0 \%)$ & $144(36 \cdot 3 \%)$ \\
\hline Neonatal $^{\mathrm{c}}$ & \multicolumn{2}{|l|}{$209(17 \cdot 7 \%)$} & $209(52 \cdot 0 \%)$ & $0(0 \%)$ \\
\hline Surgery or burn & \multicolumn{2}{|l|}{$86(7 \cdot 3 \%)$} & $28(7 \cdot 0 \%)$ & $58(14 \cdot 6 \%)$ \\
\hline Technology dependence $^{\mathrm{d}}$ & \multicolumn{2}{|l|}{$42(3 \cdot 6 \%)$} & $26(6 \cdot 5 \%)$ & $16(4 \cdot 0 \%)$ \\
\hline Solid organ transplantation & \multicolumn{2}{|l|}{$17(1.4 \%)$} & $0(0 \%)$ & $17(4 \cdot 3 \%)$ \\
\hline$>1$ condition & \multicolumn{2}{|l|}{$159(13 \cdot 5 \%)$} & $56(13 \cdot 9 \%)$ & $103(25 \cdot 9 \%)$ \\
\hline Hospital acquired sepsis & $431(36 \cdot 5 \%)$ & $16(4 \cdot 2 \%)$ & $243(60 \cdot 4 \%)$ & $172(43 \cdot 3 \%)$ \\
\hline \multicolumn{4}{|l|}{ CVAD present at time of } & $276(69 \cdot 5 \%)$ \\
\hline $\begin{array}{l}\text { Length of stay after sepsis } \\
\text { onset }^{\mathrm{e}} \text { (days) }\end{array}$ & \multirow[t]{2}{*}{$13(8-29)$} & \multirow[t]{2}{*}{$9(5-13)$} & \multirow[t]{2}{*}{$21(12-65)$} & $14(8-29)$ \\
\hline \multicolumn{2}{|l|}{ Antibiotic therapy } & & & \\
\hline $\begin{array}{l}\text { Adequate empiric antibiotic } \\
\text { treatment }^{\mathrm{f}}\end{array}$ & $1020(86 \cdot 4 \%)$ & $350(91 \cdot 6 \%)$ & $343(85 \cdot 5 \%)$ & $327(82 \cdot 4 \%)$ \\
\hline \multirow{2}{*}{\multicolumn{5}{|c|}{$\begin{array}{l}\text { Length of antibiotic } \\
\text { treatment }^{\mathrm{g}} \text { (days) }\end{array}$}} \\
\hline & & & & \\
\hline \multicolumn{5}{|l|}{$\begin{array}{l}\text { Categorical variables } \\
\text { and interquartile range } \\
\text { for each variable. }\end{array}$} \\
\hline \multicolumn{5}{|c|}{$\begin{array}{l}\text { a data not available in } 106 .{ }^{b} \text { More than one comorbidity may be present in a child, numbers and } \\
\text { percentages do not add up. }{ }^{\mathrm{c}} \text { Gestational age }<27 \text { weeks, birthweight }<750 \mathrm{~g} \text {, history of mechanical }\end{array}$} \\
\hline \multicolumn{5}{|c|}{ ventilation, history of necrotizing colitis. ${ }^{\mathrm{d}}$ Central line, or urinary catheter, or ventriculo- } \\
\hline \multicolumn{5}{|c|}{ have any other comorbidity. ${ }^{\mathrm{e}}$ data not available in 11 episodes (discharge to another facility; still } \\
\hline hospitalized). ${ }^{\mathrm{f}}$ data not avail & le in 1 episoc & hild died bef & eceiving anti & treatment). \\
\hline
\end{tabular}

(C) 2017. This manuscript version is made available under the CC-BY-NC-ND 4.0 license http://creativecommons.org/licenses/by-nc-nd/4.0/ 
Author Manuscript Published in final edited form as: Lancet Child Adolesc Health. 2017 Oct;1(2):124-133 DOI: http://dx.doi.org/10.1016/S2352-4642(17)30010-X

\section{Table 2 - Site of infection and pathogens identified in neonates and children with blood culture-proven bacterial sepsis}

\begin{tabular}{|c|c|c|c|c|}
\hline & $\begin{array}{l}\text { All episodes } \\
(\mathrm{n}=1181, \text { in } \\
1096 \text { children })\end{array}$ & $\begin{array}{l}\text { Episodes in } \\
\text { previously healthy } \\
\text { children } \\
(\mathrm{n}=382 \text {, in } 379 \\
\text { children) }\end{array}$ & $\begin{array}{l}\text { Episodes in } \\
\text { neonates } \\
\text { ( } \mathrm{n}=402 \text {, in } 391 \\
\text { infants) }\end{array}$ & $\begin{array}{l}\text { Episodes in } \\
\text { children with } \\
\text { comorbidities } \\
\text { ( } \mathrm{n}=397, \text { in } 341 \\
\text { children) }\end{array}$ \\
\hline \multicolumn{5}{|l|}{ Site of infection } \\
\hline Primary bloodstream infection & $242(20 \cdot 5 \%)$ & $49(12 \cdot 8 \%)$ & $146(36 \cdot 3 \%)$ & $47(11 \cdot 8 \%)$ \\
\hline $\begin{array}{l}\text { Central line-associated } \\
\text { bloodstream infection }\end{array}$ & \multicolumn{3}{|c|}{ Central line-associated } & $202(50 \cdot 9 \%)$ \\
\hline Urinary tract infection & $128(10 \cdot 8 \%)$ & $56(14 \cdot 7 \%)$ & $35(8 \cdot 7 \%)$ & $37(9 \cdot 3 \%)$ \\
\hline Pneumonia & $112(9 \cdot 5 \%)$ & $76(19 \cdot 9 \%)$ & $22(5 \cdot 5 \%)$ & $14(3 \cdot 5 \%)$ \\
\hline $\begin{array}{l}\text { Central nervous system } \\
\text { infection }\end{array}$ & $85(7 \cdot 2 \%)$ & $53(13 \cdot 9 \%)$ & $25(6 \cdot 2 \%)$ & $7(1 \cdot 8 \%)$ \\
\hline Bone and joint infection & $68(5 \cdot 8 \%)$ & $59(15 \cdot 4 \%)$ & $4(1 \cdot 0 \%)$ & $5(1 \cdot 3 \%)$ \\
\hline $\begin{array}{l}\text { Gastrointestinal system } \\
\text { infection }\end{array}$ & $72(6 \cdot 1 \%)$ & $18(4 \cdot 7 \%)$ & $22(5 \cdot 5 \%)$ & $32(8 \cdot 1 \%)$ \\
\hline Skin and soft tissue infection & $51(4 \cdot 3 \%)$ & $25(6 \cdot 5 \%)$ & $12(3 \cdot 0 \%)$ & $14(3 \cdot 5 \%)$ \\
\hline Surgical site infection & $17(1 \cdot 4 \%)$ & $1(0 \cdot 3 \%)$ & $4(1 \cdot 0 \%)$ & $12(3 \cdot 0 \%)$ \\
\hline Ear, Nose, and Throat infection & $29(2 \cdot 5 \%)$ & $23(6 \cdot 0 \%)$ & $4(1 \cdot 0 \%)$ & $2(0 \cdot 5 \%)$ \\
\hline $\begin{array}{l}\text { Cardiovascular system } \\
\text { infection }\end{array}$ & $10(0 \cdot 8 \%)$ & $1(0 \cdot 3 \%)$ & $1(0 \cdot 2 \%)$ & $8(2 \cdot 0 \%)$ \\
\hline Toxic shock Syndrome & $8(0 \cdot 7 \%)$ & $6(1 \cdot 6 \%)$ & $0(0 \%)$ & $2(0 \cdot 5 \%)$ \\
\hline Other specific infection type & $32(2 \cdot 7 \%)$ & $15(3 \cdot 9 \%)$ & $2(0 \cdot 5 \%)$ & $15(3 \cdot 8 \%)$ \\
\hline \multicolumn{5}{|l|}{ Pathogens } \\
\hline Gram positive bacteria & $729(61 \cdot 7 \%)$ & $260(68 \cdot 1 \%)$ & $261(64 \cdot 9 \%)$ & $208(52 \cdot 4 \%)$ \\
\hline S. aureus & $177(15 \cdot 0 \%)$ & $66(17 \cdot 3 \%)$ & $48(11 \cdot 9 \%)$ & $63(15 \cdot 9 \%)$ \\
\hline $\begin{array}{l}\text { Coagulase negative } \\
\text { staphylococci }\end{array}$ & $135(11 \cdot 4 \%)$ & $0(0 \%)$ & $86(21 \cdot 4 \%)$ & $49(12 \cdot 3 \%)$ \\
\hline S. pneumoniae & $118(10 \cdot 0 \%)$ & $90(23 \cdot 6 \%)$ & $4(1 \cdot 0 \%)$ & $24(6 \cdot 0 \%)$ \\
\hline Viridans group streptococci & $59(5 \cdot 0 \%)$ & $15(3 \cdot 9 \%)$ & $9(2 \cdot 2 \%)$ & $35(8 \cdot 8 \%)$ \\
\hline Group A streptococci & $53(4 \cdot 5 \%)$ & $47(12 \cdot 3 \%)$ & $3(0 \cdot 7 \%)$ & $3(0 \cdot 8 \%)$ \\
\hline Group B streptococci & $105(8 \cdot 9 \%)$ & $24(6 \cdot 3 \%)$ & $79(19 \cdot 7 \%)$ & $2(0 \cdot 5 \%)$ \\
\hline Enterococcus species & $42(3 \cdot 6 \%)$ & $6(1 \cdot 6 \%)$ & $16(4 \cdot 0 \%)$ & $20(5 \cdot 0 \%)$ \\
\hline Other Gram positive bacteria & $40(3 \cdot 4 \%)$ & $12(3 \cdot 1 \%)$ & $16(4 \cdot 0 \%)$ & $12(3 \cdot 0 \%)$ \\
\hline Gram negative bacteria & $452(38 \cdot 3 \%)$ & $122(31 \cdot 9 \%)$ & $141(35 \cdot 1 \%)$ & $189(47 \cdot 6 \%)$ \\
\hline E.coli & $242(20 \cdot 5 \%)$ & $62(16 \cdot 2 \%)$ & $96(23 \cdot 9 \%)$ & $84(21 \cdot 2 \%)$ \\
\hline
\end{tabular}

(C) 2017. This manuscript version is made available under the CC-BY-NC-ND 4.0 license http://creativecommons.org/licenses/by-nc-nd/4.0/ 
Author Manuscript Published in final edited form as: Lancet Child Adolesc Health. 2017 Oct;1(2):124-133 DOI: http://dx.doi.org/10.1016/S2352-4642(17)30010-X

\begin{tabular}{|lllll} 
H. influenzae & $21(1 \cdot 8 \%)$ & $17(4 \cdot 5 \%)$ & $1(0 \cdot 2 \%)$ & $3(0 \cdot 8 \%)$ \\
\hline Klebsiella species & $55(4.7 \%)$ & $0(0 \%)$ & $20(5 \cdot 0 \%)$ & $35(8 \cdot 8 \%)$ \\
N. meningitidis & $28(2 \cdot 4 \%)$ & $26(6 \cdot 8 \%)$ & $0(0 \%)$ & $2(0 \cdot 5 \%)$ \\
P. aeruginosa & $24(2.0 \%)$ & $2(0.5 \%)$ & $4(1 \cdot 0 \%)$ & $18(4.5 \%)$ \\
Other Gram negative bacteria & $82(6.9 \%)$ & $15(3 \cdot 9 \%)$ & $20(5 \cdot 0 \%)$ & $47(11 \cdot 8 \%)$
\end{tabular}

Data are $\mathrm{n}(\%)$. Column percentages are given. 
Author Manuscript Published in final edited form as: Lancet Child Adolesc Health. 2017 Oct;1(2):124-133 DOI: http://dx.doi.org/10.1016/S2352-4642(17)30010-X

\section{Table 3 - Severity of sepsis episodes in neonates and children with blood culture-proven bacterial sepsis}

\begin{tabular}{|c|c|c|c|c|}
\hline & $\begin{array}{l}\text { All episodes } \\
(n=1181, \text { in } \\
1096 \text { children })\end{array}$ & $\begin{array}{l}\text { Episodes in } \\
\text { previously } \\
\text { healthy children } \\
(\mathrm{n}=382 \text {, in } 379 \\
\text { children) }\end{array}$ & $\begin{array}{l}\text { Episodes in } \\
\text { neonates } \\
\text { (n=402, in } 391 \\
\text { infants) }\end{array}$ & $\begin{array}{l}\text { Episodes in } \\
\text { children with } \\
\text { comorbidities } \\
(\mathrm{n}=397 \text {, in } 341 \\
\text { children) }\end{array}$ \\
\hline \multicolumn{5}{|l|}{ Organ dysfunctions } \\
\hline No organ dysfunction present & $726(61 \cdot 5 \%)$ & $281(73 \cdot 6 \%)$ & $174(43 \cdot 3 \%)$ & $271(68 \cdot 3 \%)$ \\
\hline 1 organ dysfunction & $224(19 \cdot 0 \%)$ & $43(11 \cdot 3 \%)$ & $132(32 \cdot 8 \%)$ & $49(12 \cdot 3 \%)$ \\
\hline 2 organ dysfunctions & $111(9 \cdot 4 \%)$ & $25(6 \cdot 5 \%)$ & $51(12 \cdot 7 \%)$ & $35(8 \cdot 8 \%)$ \\
\hline 3 organ dysfunctions & $56(4 \cdot 7 \%)$ & $9(2 \cdot 4 \%)$ & $23(5 \cdot 7 \%)$ & $24(6 \cdot 0 \%)$ \\
\hline 4 organ dysfunctions & $30(2 \cdot 5 \%)$ & $9(2 \cdot 4 \%)$ & $14(3 \cdot 5 \%)$ & $7(1 \cdot 8 \%)$ \\
\hline 5 organ dysfunctions & $20(1 \cdot 7 \%)$ & $10(2 \cdot 6 \%)$ & $5(1 \cdot 2 \%)$ & $5(1 \cdot 3 \%)$ \\
\hline 6 organ dysfunctions & $14(1 \cdot 2 \%)$ & $5(1 \cdot 3 \%)$ & $3(0 \cdot 7 \%)$ & $6(1 \cdot 5 \%)$ \\
\hline PICU/ NICU admission ${ }^{a}$ & $570(48 \cdot 3 \%)$ & $108(28 \cdot 3 \%)$ & $323(80 \cdot 3 \%)$ & $139(35 \cdot 0 \%)$ \\
\hline $\begin{array}{l}\text { PICU/ NICU admission due to } \\
\text { sepsis }\end{array}$ & $271(23 \cdot 0 \%)$ & $103(27 \cdot 0 \%)$ & $100(24 \cdot 9 \%)$ & $68(17 \cdot 1 \%)$ \\
\hline Length of PICU stay ${ }^{b}$ (days) & $14(4-52)$ & $4(2-9)$ & $25(8-66)$ & $14(3-68)$ \\
\hline $\begin{array}{l}\text { Length of PICU stay due to } \\
\text { sepsis }^{c} \text { (days) }\end{array}$ & $4(2-11)$ & $4(2-9)$ & $6(4-17)$ & $3(1-9)$ \\
\hline Invasive ventilation $^{a}$ & $307(26 \cdot 0 \%)$ & $54(14 \cdot 2 \%)$ & $183(45 \cdot 5 \%)$ & $70(17 \cdot 6 \%)$ \\
\hline Invasive ventilation due to sepsis & $201(17 \cdot 0 \%)$ & $51(13 \cdot 4 \%)$ & $109(27 \cdot 1 \%)$ & $41(10 \cdot 3 \%)$ \\
\hline Non-invasive ventilation & $178(15 \cdot 1 \%)$ & $17(4 \cdot 5 \%)$ & $141(35 \cdot 1 \%)$ & $20(5 \cdot 0 \%)$ \\
\hline $\begin{array}{l}\text { Non-invasive ventilation due to } \\
\text { sepsis }\end{array}$ & $70(5 \cdot 9 \%)$ & $14(3 \cdot 7 \%)$ & $50(12 \cdot 4 \%)$ & $6(1 \cdot 5 \%)$ \\
\hline Inotrope requirement $^{a}$ & $177(15 \cdot 0 \%)$ & $46(12 \cdot 0 \%)$ & $66(16 \cdot 4 \%)$ & $65(16 \cdot 4 \%)$ \\
\hline Case fatality & $82(6 \cdot 9 \%)$ & $10(2 \cdot 6 \%)$ & $45(11 \cdot 2 \%)$ & $27(6 \cdot 8 \%)$ \\
\hline $\begin{array}{l}\text { Time to death from sepsis onset } \\
\text { (days) }\end{array}$ & $2(1-7)$ & $2(0-2)$ & $1(1-5)$ & $6(1-16)$ \\
\hline
\end{tabular}

PICU=pediatric intensive care unit. NICU=neonatal intensive care unit.

Categorical variables are given as frequencies and percentages, continuous variables as median and interquartile range. Column percentages are given. Percentages are based upon available data for each variable.

adata not available in 1 episode. ${ }^{b}$ data not available in 31 episodes. ${ }^{c}$ data not available in 14 episodes.

(C) 2017. This manuscript version is made available under the CC-BY-NC-ND 4.0 license http://creativecommons.org/licenses/by-nc-nd/4.0/ 
Author Manuscript Published in final edited form as: Lancet Child Adolesc Health. 2017 Oct;1(2):124-133

DOI: http://dx.doi.org/10.1016/S2352-4642(17)30010-X

\section{Table 4: Risk factors for death in neonates and children with blood culture-proven bacterial sepsis}

\begin{tabular}{|c|c|c|c|c|c|c|}
\hline & \multirow{2}{*}{$\begin{array}{l}\text { sepsis episodes in which } \\
\text { children survived } \\
n=1023\end{array}$} & \multirow{2}{*}{$\begin{array}{l}\text { sepsis episodes in } \\
\text { which children died } \\
\mathrm{n}=73\end{array}$} & \multicolumn{2}{|c|}{ Unadjusted model } & \multicolumn{2}{|c|}{ Adjusted model } \\
\hline & & & OR $(95 \% \mathrm{CI})$ & $\mathrm{p}$ value $\mathrm{b}^{\mathrm{b}}$ & OR $(95 \% \mathrm{CI})$ & $\mathrm{p}$ value ${ }^{\mathrm{b}}$ \\
\hline Patient group & & & & $0 \cdot 0003$ & & $0 \cdot 0007$ \\
\hline Previously healthy children $^{a}, n=375$ & $366(97 \cdot 6 \%)$ & $9(2 \cdot 4 \%)$ & & & & \\
\hline Neonates, $\mathbf{n = 3 9 1}$ & $349(89 \cdot 3 \%)$ & $42(10 \cdot 7 \%)$ & $4 \cdot 19(1 \cdot 94-9 \cdot 04)$ & & $4 \cdot 41(1 \cdot 75-11 \cdot 1)$ & \\
\hline Children with comorbidities, $n=330$ & $308(93 \cdot 3 \%)$ & $22(6 \cdot 7 \%)$ & $2 \cdot 86(1 \cdot 28-6 \cdot 40)$ & & $4 \cdot 97(1 \cdot 84-13 \cdot 4)$ & \\
\hline Number of organ dysfunctions & & & & $<0 \cdot 0001$ & & $<0 \cdot 0001$ \\
\hline No organ dysfunction ${ }^{a}, n=671$ & $667(99 \cdot 4 \%)$ & $4(0 \cdot 6 \%)$ & & & & \\
\hline 1 organ dysfunction, $n=207$ & $198(95 \cdot 7 \%)$ & $9(4 \cdot 3 \%)$ & $5 \cdot 78(1 \cdot 68-19 \cdot 9)$ & & $4 \cdot 97(1 \cdot 43-17 \cdot 2)$ & \\
\hline 2 or 3 organ dysfunctions, $n=160$ & $127(79 \cdot 4 \%)$ & $33(20 \cdot 6 \%)$ & $56 \cdot 7(18 \cdot 6-173)$ & & $49 \cdot 5(16 \cdot 1-152)$ & \\
\hline 4 to 6 organ dysfunctions, $n=58$ & $31(53 \cdot 4 \%)$ & $27(46 \cdot 6 \%)$ & $212(64 \cdot 0-704)$ & & $275(78 \cdot 6-962)$ & \\
\hline
\end{tabular}

$\mathrm{OR}=$ odds ratio. $\mathrm{CI}=$ confidence interval. Data are $\mathrm{n}(\%)$ unless otherwise specified. Row percentages are given.

Unadjusted and adjusted OR for death investigating potential risk factors patient group and number of organ dysfunctions in multilevel binomial regression. The adjusted model was adjusted for all variables listed. Outcome was death within the first 30 days after sepsis onset (yes/no).

${ }^{\mathrm{a}}$ reference category. ${ }^{\mathrm{b}} \mathrm{p}$ value from likelihood ratio test 
Author Manuscript Published in final edited form as: Lancet Child Adolesc Health. 2017

Oct;1(2):124-133 DOI: http://dx.doi.org/10.1016/S2352-4642(17)30010-X

\section{Figures}

\section{Figure 1: Flow chart of sepsis episodes included in the Swiss Pediatric Sepsis Study}

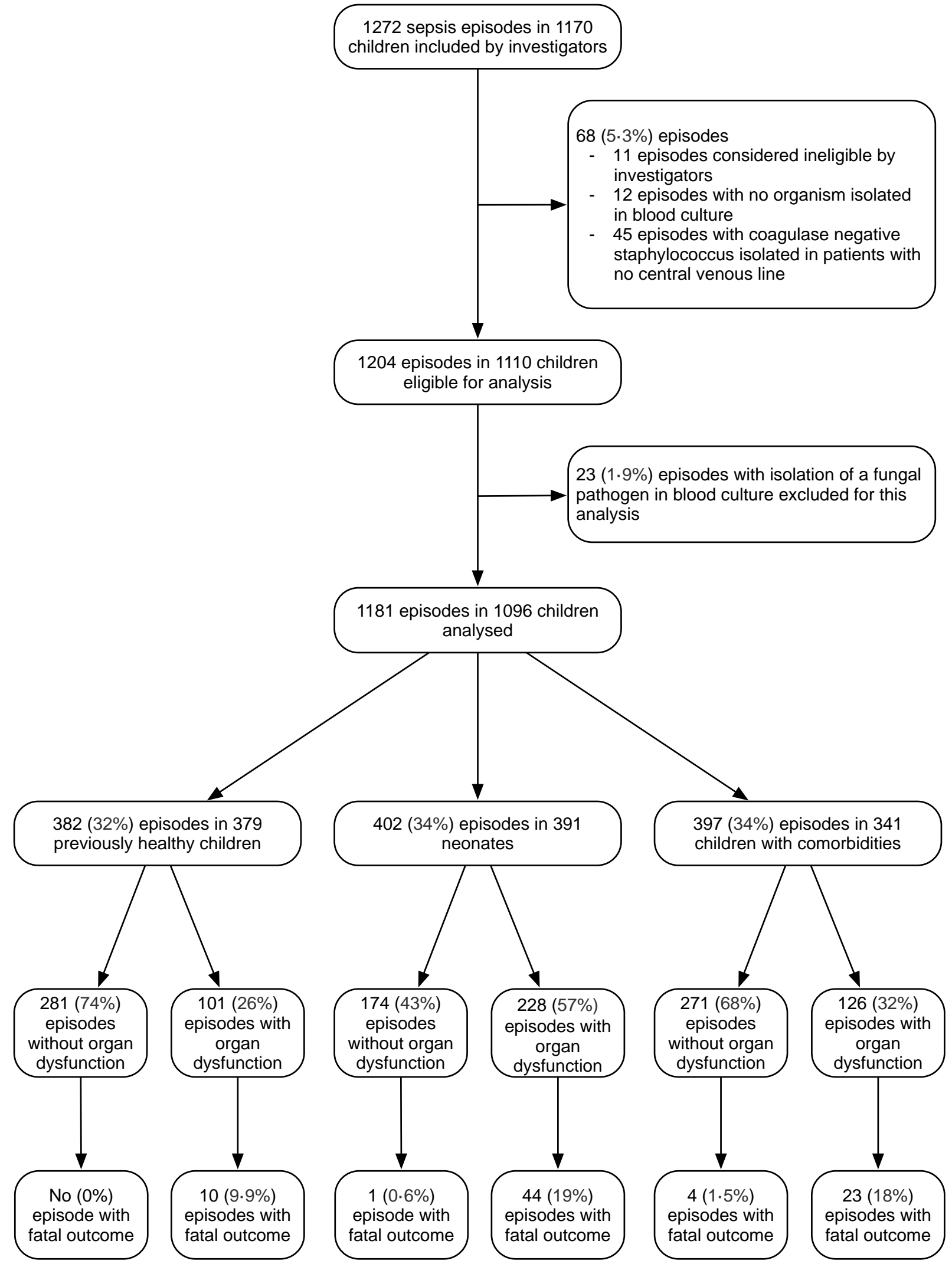


Author Manuscript Published in final edited form as: Lancet Child Adolesc Health. 2017

Oct;1(2):124-133 DOI: http://dx.doi.org/10.1016/S2352-4642(17)30010-X

\section{Figure 2: Incidence of blood culture-proven bacterial sepsis in the years 2012-2015 in}

\section{Switzerland, grouped by age.}

Red horizontal lines show the crude incidence $(n=1126)$, as measured in the ten participating study centers, black horizontal lines the estimated national incidence of all blood culture-proven bacterial sepsis in Switzerland (Panel A), and blood culture-proven bacterial sepsis with organ dysfunction (n=439) (Panel B). The estimate of national sepsis incidence is based on the assumption that participating hospitals captured $80 \%$ of all sepsis episodes in children up to 16 years in Switzerland and $90 \%$ of all episodes with organ dysfunction (irrespective of age). Vertical lines represent the $95 \%$ confidence intervals around the point estimates for each age group.

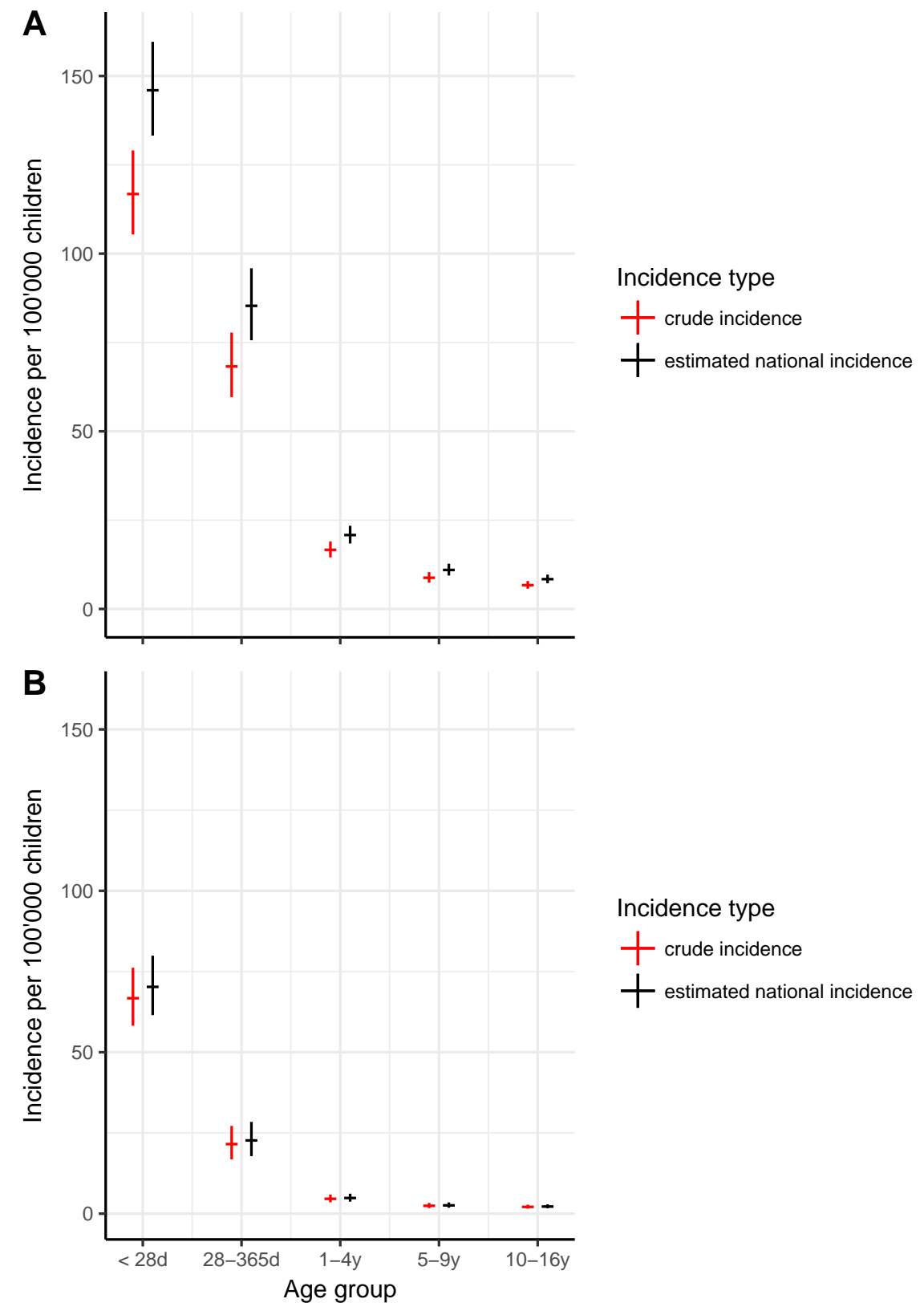

(C) 2017. This manuscript version is made available under the CC-BY-NC-ND 4.0 license http://creativecommons.org/licenses/by-nc-nd/4.0/ 
Author Manuscript Published in final edited form as: Lancet Child Adolesc Health. 2017 Oct;1(2):124-133 DOI: http://dx.doi.org/10.1016/ S2352-4642(17)30010-X

\section{Figure 3: Age distribution of sites of infection and responsible pathogens causing blood culture-proven bacterial sepsis in}

\section{children.}

Sites of infection are shown for the three patient groups (A) and separately for previously healthy children $\geq 28$ days of age (B), and for neonates, and children with comorbidities $\geq 28$ days of age (C) grouped by age. Pathogens isolated in blood culture are shown for the three patient groups (D), and separately for previously healthy children $\geq 28$ days of age (E), and for neonates, and children with comorbidities $\geq 28$ days of age (F) grouped by age.

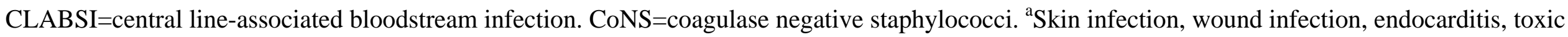
shock syndrome, ear-nose-throat infection, other non-specified focal infection. ${ }^{\mathrm{b}}$ P. aeruginosa, Klebsiella spp., N. meningitidis, H. influenzae, other Gram-negative pathogens. ${ }^{\mathrm{c}}$ Enterococcus spp., viridans group streptococci, other Gram-positive pathogens
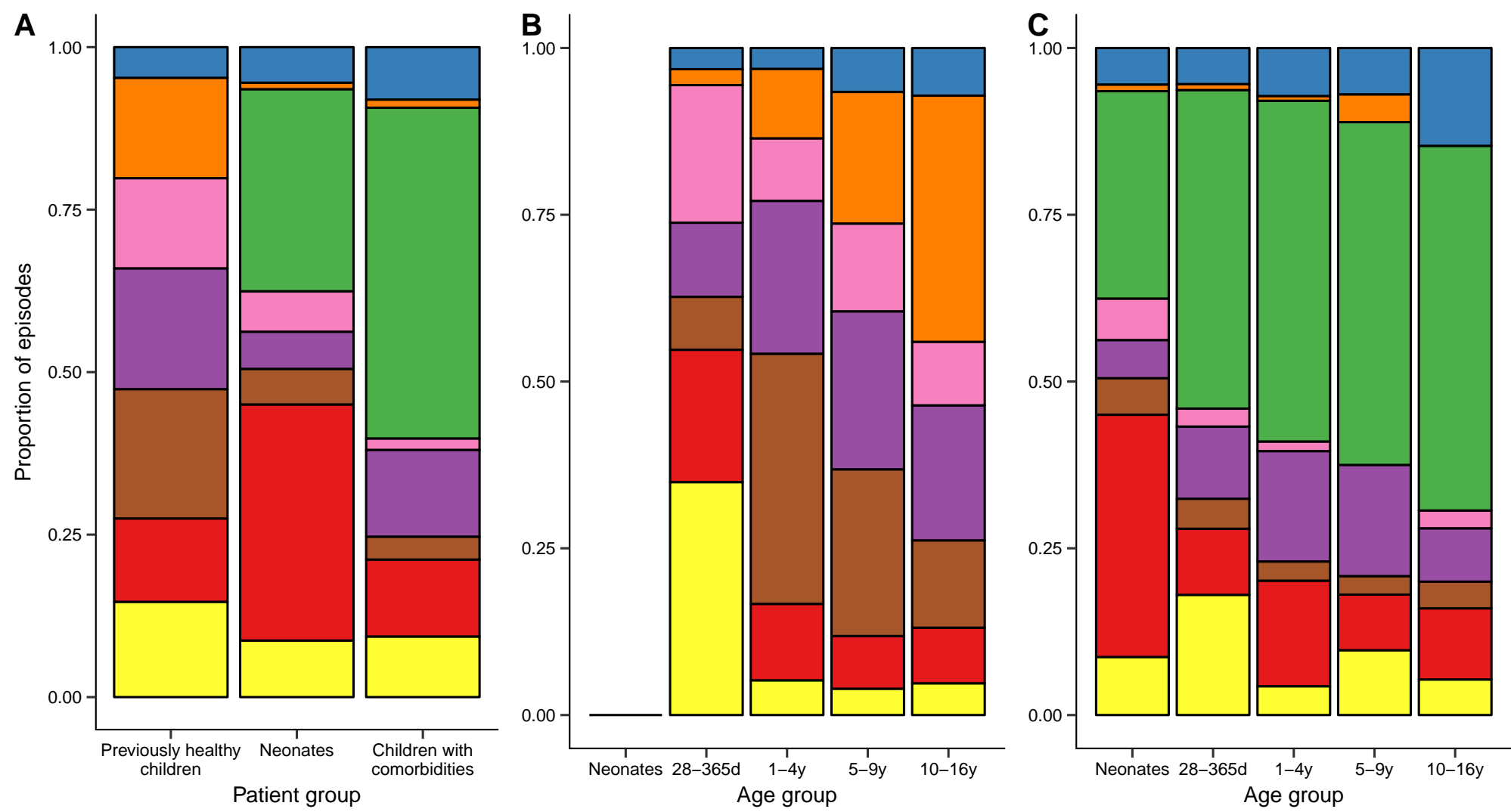

Site of infection

Abdominal infection

Bone and joint infection

Central nervous system infection

CLABSI

Other infection type a

Pneumonia

Primary bloodstream infection

Urinary tract infection

(C) 2017. This manuscript version is made available under the CC-BY-NC-ND 4.0 license

http://creativecommons.org/licenses/by-nc-nd/4.0/ 
Author Manuscript Published in final edited form as: Lancet Child Adolesc Health. 2017 Oct;1(2):124-133

DOI: http://dx.doi.org/10.1016/S2352-4642(17)30010-X
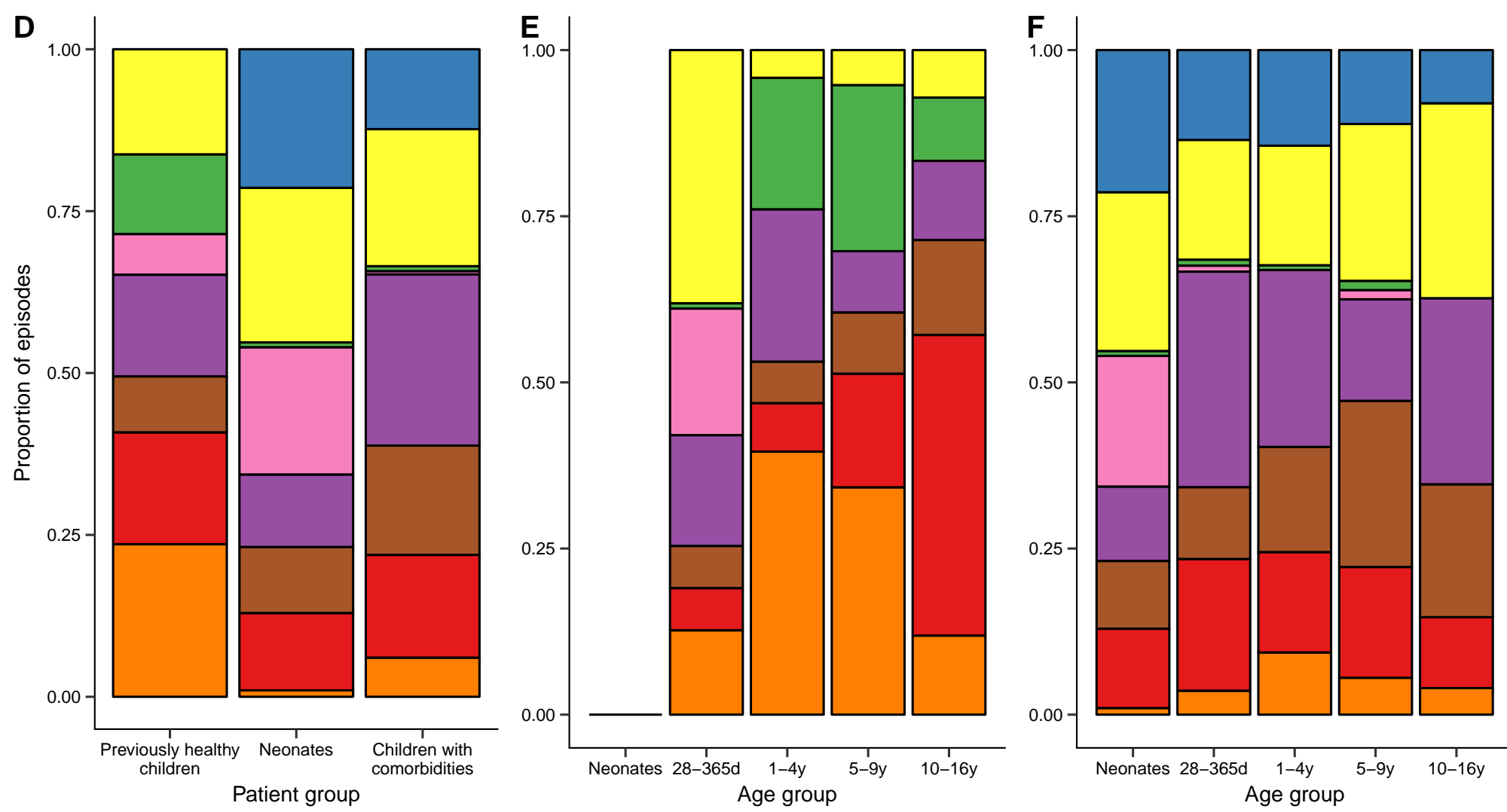

Pathogens

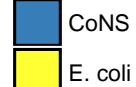

Group A Streptococci

Group B Streptococci

other Gram negative pathogens ${ }^{b}$

other Gram positive pathogens ${ }^{c}$

aureus

S. pneumoniae 
Author Manuscript Published in final edited form as: Lancet Child Adolesc Health. 2017

Oct;1(2):124-133 DOI: http://dx.doi.org/10.1016/S2352-4642(17)30010-X

Figure 4: Impact of organ dysfunction on case fatality ratio in children with sepsis.

Horizontal lines represent point estimates of the case fatality ratio in children with sepsis stratified by number of organ dysfunctions present. Vertical lines represent the $95 \%$ confidence intervals around the point estimates for each group.

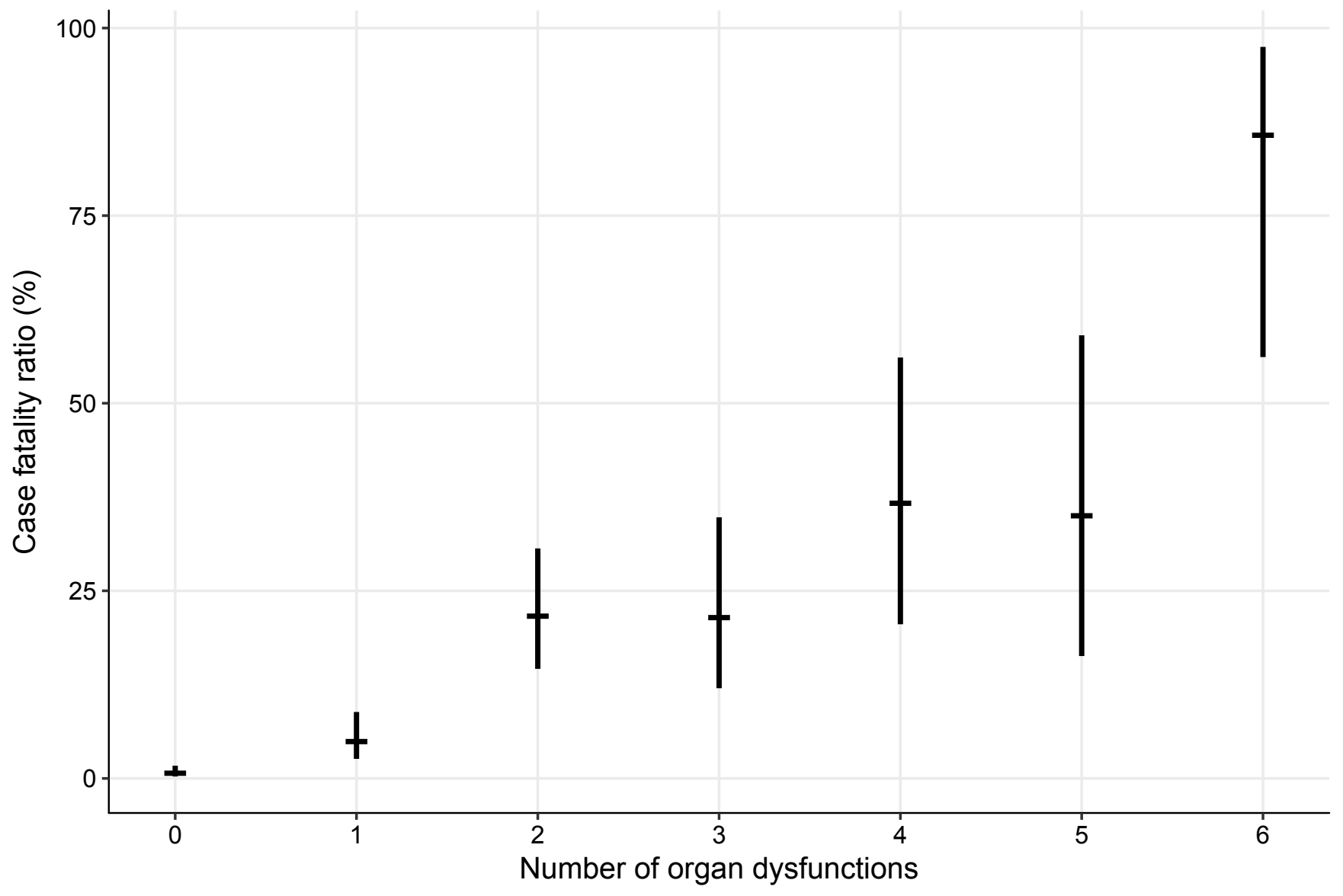

(C) 2017. This manuscript version is made available under the CC-BY-NC-ND 4.0 license http://creativecommons.org/licenses/by-nc-nd/4.0/ 